\title{
Sequencing results from multiple individuals of different ethnicities strongly question the existence of the KCNE1B pseudogene
}

\author{
Marta Diñeiro ${ }^{1} \cdot$ Guadalupe A. Cifuentes $^{1} \cdot$ Raquel Capín $^{1} \cdot$ Adrián Santiago $^{1} \cdot$ Andrea Otero $^{1} \cdot$ David Castillo $^{2}$. \\ Patricia C. Pruneda ${ }^{2} \cdot$ Gonzalo R. Ordóñez $^{2} \cdot$ Rubén Cabanillas $^{1} \cdot$ Juan Cadiñanos $\mathbb{D}^{1}$
}

Received: 2 August 2019 / Accepted: 20 August 2019 / Published online: 16 September 2019

(c) The Author(s) 2019. This article is published with open access

\section{To the Editor:}

In regard to the Viewpoint by Pantou et al. "The potential presence of the highly similar paralogue gene $K C N E 1 B$ blurs the genetic basis of $K C N E 1$-LQTS patients" [1], we have collected the following evidence in our laboratory, strongly supporting the possibility that the pseudogene $K C N E 1 B$, absent from the GRCh37 version of the human genome, is an artifact introduced in GRCh38:

We have evaluated the genotype of the rs1805127 SNP on 58 deaf patients analyzed with the OTOgenics Next Generation Sequencing (NGS) capture panel [2]. This SNP was selected because the reference nucleotide for $K C N E 1(\mathrm{~T})$ is different from the reference nucleotide for the paralogue position of the KCNE1B pseudogene (C), according to GRCh38 (Supplementary Fig. 1). Considering together all reads potentially originating from $K C N E 1$ or $K C N E 1 B$, all patients show variant reads/total reads ratios of $0,0.5$ or 1 , as it would be expected for the existence of a single locus with two alleles, instead of two paralogue loci with four alleles. If $K C N E 1 B$ was not an artifact, since the sequences surrounding rs1805127 are identical between $K C N E 1$ and the corresponding paralogue $K C N E 1 B$ region, reads originating from all four alleles would be mapped together and KCNE1 heterozygous patients with a ratio of 0.25 should be identified (Supplementary Table 1).

Supplementary information The online version of this article (https:// doi.org/10.1038/s41431-019-0502-6) contains supplementary material, which is available to authorized users.

Juan Cadiñanos

jcb@imoma.es

1 Instituto de Medicina Oncológica y Molecular de Asturias (IMOMA) S. A., Oviedo, Spain

2 DREAMgenics S. L., Oviedo, Spain
We have evaluated a daughter-father-mother trio in which the father and the daughter are heterozygous for the rs74315445 KCNE1 SNV, while the mother is wild type. PCR was performed using primers that, according to GRCh38, should not be able to distinguish between KCNE1 and $K C N E 1 B$ (Supplementary Fig. 1). Sanger sequencing of the obtained PCR products shows heterozygous peaks with identical heights for both alleles from the father's and the daughter's DNAs, which is not compatible with a variant affecting only one of four alleles. Although the father could be homozygous for the variant in the KCNEI locus (which could explain the similar height of both peaks in his sample if $K C N E 1 B$ was real), the mother is wild type and, therefore, the daughter could not possibly inherit two variant alleles from her parents (Supplementary Fig. 2).

We have PCR amplified the regions containing the positions for rs1805127 and rs1805128 SNPs on DNA from lymphoblastoid cell lines from ten individuals representing ten different ethnic origins from four continents in the same conditions unable to distinguish $K C N E 1$ from $K C N E 1 B$. In all cases, Sanger sequencing of the PCR product shows clear wild type or heterozygous genotypes for rs 1805127 (with peaks of identical heights for the alternative and reference $K C N E 1$ alleles in heterozygotes) and homozygous $K C N E 1$ reference (C/C) genotypes for rs1805128, with no sign of the reference $K C N E 1 B(\mathrm{~T})$ allele (Supplementary Table 2 and Supplementary Fig. 3).

In our opinion, these data, together with those presented by Pantou et al., strongly suggest that $K C N E 1 B$ is an artifact that should be reviewed and curated. This would reduce the probabilities of false negative results caused by misalignment of variant reads originating from the true and clinically relevant KCNE1 locus to the KCNE1B region of the GRCh38 reference genome.

Acknowledgements Work performed at IMOMA has been supported by Fundación María Cristina Masaveu Peterson. 
Publisher's note Springer Nature remains neutral with regard to jurisdictional claims in published maps and institutional affiliations.

Open Access This article is licensed under a Creative Commons Attribution 4.0 International License, which permits use, sharing, adaptation, distribution and reproduction in any medium or format, as long as you give appropriate credit to the original author(s) and the source, provide a link to the Creative Commons license, and indicate if changes were made. The images or other third party material in this article are included in the article's Creative Commons license, unless indicated otherwise in a credit line to the material. If material is not included in the article's Creative Commons license and your intended use is not permitted by statutory regulation or exceeds the permitted use, you will need to obtain permission directly from the copyright holder. To view a copy of this license, visit http://creativecommons. org/licenses/by/4.0/.

\section{References}

1. Pantou MP, Gourzi P, Degiannis D. The potential presence of the highly similar paralogue gene KCNE1B blurs the genetic basis of KCNE1-LQTS patients. Eur J Hum Genet. 2019;27:1175-7.

2. Cabanillas R, Diñeiro M, Cifuentes GA, Castillo D, Pruneda PC, Álvarez $\mathrm{R}$, et al. Comprehensive genomic diagnosis of nonsyndromic and syndromic hereditary hearing loss in Spanish patients. BMC Med Genom. 2018;11:58. 